\title{
Agenda Change in Western Development Organizations: From Hard Production to Soft, Timeless, Placeless Policy
}

\section{Robert H. Wade}

\begin{abstract}
Professor Robert Wade, Professor of Political Economy and Development at the London School of Economics, delivered the keynote address for the 11th Annual Conference on the Management of the Pakistan Economy.

This is a talk about the dramatic change in the understanding of what constitutes "development" that occurred in the West and in much of the developing world after the mid 1980s. Before that time it was widely understood that development meant rising overall "prosperity" and that heavy investment in infrastructure and in industry were key drivers. After the mid 1980s the content of development came to be "extreme poverty reduction", "humanitarian assistance", "primary school education", "primary health care", "anti-corruption".

Why this change? I argue that it was due to several factors: (1) the end of the Cold War, and the resulting change in the geopolitical strategy of Western states led by the US; (2) the increasing strength of "post-materialist" values in developed countries and their translation into the content of Western development thinking (eg World Bank, USAID, DfID); (3) business interests in the West; and (4) continued Western control of inter-state organizations that are meant to be organizations for the world (eg World Bank). There are now small signs of change in favor of investment in production and infrastructure, thanks partly to the recent emergence of inter-state "by- pass" organizations not controlled by Western states (such as the New Development Bank, the Asia Infrastructure Investment Bank).
\end{abstract}

Keywords: Development, production, western countries, policy.

\section{JEL classification: O29.}

\section{Introduction}

In 1972, the president of the World Bank, Robert McNamara, visited Somalia - the first visit of a World Bank president to that country. He pledged a large loan to build a port. This port continues as Somalia's main

\footnotetext{
* Professor of Political Economy and Development, London School of Economics.
} 
port, but it badly needs upgrading. In 2014, Jim Kim was the second World Bank president to visit Somalia. The high point of his visit was an announcement that the Bank had helped develop a mobile phone app that would allow the government to track the number of people in poverty in Somalia, quarter by quarter. No announcement of a loan for upgrading the port or for any of the other infrastructure Somalia desperately needs. Median electricity consumption in Ethiopia (next door to Somalia) is 1/255 that of the median American; median Somali electricity consumption is lower than the Ethiopian (Pritchett, 2015).

This contrast between the World Bank in action in 1972 and in 2014 captures the dramatic change in the "zeitgeist" of "foreign aid" from Western states that occurred in the 1980s: away from infrastructure, industry, and even agriculture, towards "poverty," "rural," "social," "health," "governance," and "market liberalization." Inside the World Bank during the 1980s, staff with expertise in infrastructure and industry were invited either to find employment elsewhere or to rebrand themselves as experts in "social" or "environment" or other favored sectors.

Fast forward to the Millennium Development Goals. These were formulated after 2000 to apply to the category of developing countries, with rich country aid agencies and Western multilateral development organizations having the main input. It is striking how "low-bar" or "least common denominator" they are. Goal 1 calls for reductions in extreme poverty and hunger (where extreme poverty is measured at an individual income of less than US\$1.25 per day); other goals call for "completing primary school" and "ensuring environmental sustainability." There is no mention of economic growth, employment, prosperity, productivity, secondary education, university, or research.

In 2005, I visited Addis Ababa with Joe Stiglitz and Akbar Noman (who, a decade before, had been the World Bank country economist for Ethiopia). We met with representatives of some 20 aid agencies and invited each to describe the priorities of their agency. Two points struck us. First, their priorities were almost identical. Second, the priorities did not include infrastructure or agriculture or industry. The partial exception was the Japanese representative, who listed "rural roads" among his agency's priorities. None of the others got even that far toward infrastructure and production.

The recent mission statement of USAID declares: "We partner to end extreme poverty and to promote resilient, democratic societies while 
advancing our own security and prosperity" [emphasis added]. Note that, here, US aid targets enhancing the prosperity of the US but not, apparently, that of the recipient. For the recipient, the target is not national prosperity or even poverty, but extreme poverty. The international extreme poverty line excludes some 5 billion people who live above the extreme poverty line, but below the OECD's poverty line (Pritchett, 2015).

In 2008, Justin Yifu Lin was appointed chief economist and senior vice-president at the World Bank. A Chinese citizen, he was the first chief economist from outside the G7 (almost all have been American or British). Lin championed a modest form of "industrial policy" contrary to the longprevailing ethos in the Bank, which dismissed industrial policy - whatever its theoretical rationales derived from "market failure theory" - as an excuse for corruption, rent seeking, and clientelism in developing countries. Lin's industrial policy was so modest that, as he kept stressing, it should operate only within the economy's existing comparative advantage and not push activities beyond these limits (Lin, 2012). Yet Lin himself admits that less than 10 percent of Bank economists were convinced during his tenure (which ended in 2012). One of the Bank's senior economists told me: "For every Korea, there are a hundred failures. Who would you put your money on?"

But the change in the Western aid agenda goes well beyond the change in sectoral focus, to a whole new language and grammar (Moretti \& Pestre, 2015). Here is the World Bank's annual report for 1969:

... the Bank Group continues to encourage [developing countries' transformation of agriculture] through its lending for general agricultural development, which totaled $\$ 72.2$ million in the 1969 financial year. Diversification into new crops which provide a source of cash income, or improved production of existing ones, was encouraged by loans or credits to support traditional coffee production in Burundi at its normal level, palm oil development in Cameroon, Dahomey, the Ivory Coast and Papua, afforestation in Zambia and mechanization of sorghum, sesame and cotton farming in the Sudan.

This is plain, factual prose, which gives a clear idea of where on the spatial and time dimensions (past, current, future) the various statements relate to.

By contrast, the 2008 annual report is replete with passages such as: 


\section{Leveling the playing field on global issues}

Countries in the region are emerging as key players on issues of global concern, and the Bank's role has been to support their efforts by partnering through innovative platforms for an enlarged dialogue and action on the ground as well as by supporting South-South cooperation.

What does this mean? It is much more detached from everyday language than the previous passage. It begins with a classic example of a principle - "leveling the playing field on global issues" - which no one could object to because no one can say what it means. Such abstract and opaque prose renders it difficult for the reader (and for those wishing to hold the Bank accountable) to identify what the Bank was doing, is doing, and will do. It is not possible to assess the organization's efforts "to support their efforts by partnership through innovative platforms for an enlarged dialogue" because the words have no clear empirical referents. And it is difficult to identify actors in the abstraction called "South-South cooperation."

One recalls George Orwell's remark that political speech and writing commonly contain "a mass of Latin words [which] falls upon the facts like soft snow, blurring the outline and covering up all the details" (Orwell, 1968, p. 166).

The difference between the Bank's 1969 passage and that from 2008 applies to all the annual reports after 1990 compared to those published between 1950 and the late 1970s/early 1980s. Indeed, the frequency distribution of words in the Bank's annual reports from 1948 to the present shows that, after about 1990, words close to infrastructure, agriculture, and industry fell away, and words of three other semantic clusters gained sharply (Moretti \& Pestre, 2015). The first cluster is "finance," containing words such as "portfolio," "assets," "derivative," "accrual," "guarantees," "accounting," "hedging," "default," and "swaps." The second is "management" - the second most frequently used noun in annual reports after 1990, after "loan" and ahead of "investment." Other frequently used words in the management cluster include "strategies," "opportunities," "challenges," "critical situations," and for verbs, "focusing," "strengthening," "monitor," "control," and "audit."

"Governance" is the third ascendant cluster. The word appeared for the first time, hidden away in a single sentence, in the 1990 annual report. Since then, the frequency of words in the governance cluster has taken off: 
words such as "dialogue," "stakeholders," "collaboration," and "partnerships." "Governance" in the Bank's annual reports is commonly used with the present continuous verb tense, as in "improving," "strengthening," "supporting," "including," and "promoting." The present continuous, being unanchored in time, conveys the meaning of "tireless ongoing striving for the good." The word itself and others in its cluster are always used in a one-dimensional, positive context, as though the more of their qualities in a country, the better, whereas "government" may be good or bad, and more likely bad. Indian Prime Minister Modi's motto is "less government and more governance" - whatever that means.

\section{How Can We Explain the Changes in Western Development Agendas?}

How can we explain the dramatic change in thinking about development among Western aid agencies and Western-controlled international organizations? The change has important real-world effects because, in one way or another, it has swung national development agendas in the same direction: away from infrastructure and industrialization.

I suggest several elements of an answer:

- The end of the Cold War and the change in the West's geopolitical strategy

- Aid agencies' greater responsiveness, post-Cold War, to the priorities of Western publics for their own countries (as distinct from, for developing countries)

- Stronger Western NGO campaign pressure against aid agencies that sponsor infrastructural or industrial projects with harmful social and environmental consequences

- The ascendancy of neoliberalism, with its bedrock belief that "the free market works best, except in limited cases of market failure, which include the reduction of extreme poverty"

- Western control of influential international development organizations, above all, the World Bank.

During the heyday of the Cold War, Western states used aid as a weapon to keep developing countries out of the Soviet and Chinese orbits and more than that, in countries abutting the two blocs, to create flourishing capitalist economies in order to demonstrate that capitalism works better than communism. So, in East Asia, close to Communist China, the US government poured aid into Japan, the Republic of Korea, and Taiwan, and 
the World Bank followed. These agencies even sponsored expropriative land reforms and invested heavily in infrastructure, agriculture, industry, and training. Strikingly, neither the Western agencies nor the national governments deployed much by way of "poverty" programs in East Asia. They concentrated on generating fast growth and transforming production - and the number of poor people fell dramatically (Wade, 1990). During this period, the World Bank employed many engineers, technologists, and industrial policy experts.

As the West emerged the victor of the Cold War, the geopolitical imperative of keeping developing countries out of the Soviet or Chinese orbits fell away. At the same time, euphoria took hold about the blessings of Western-led globalization for the world at large. Globalization and free markets were spreading democratic pluralism, individualism, personal freedom, and national prosperity. Asia was booming. Europe was coming together in the European Union. Middle East conflicts were subsiding. The more that countries and their constituent entities (firms, households, and governments) were integrated with the world market, with no segmentation at the national border, the better for everyone; important substitution policies and capital controls should be avoided, because they lowered the efficiency of resource use.

The main problem that could not be left to "the market" and the resources of individual developing countries was persisting extreme poverty. That is what aid should be targeted at, said the consensus; that, and help to liberalize markets and integrate into the Western-dominated world economy. And so, as noted, the World Bank's engineers and industrial policy specialists either departed or rebranded.

The fading geopolitical imperatives allowed aid priorities to be brought into closer alignment with the Western public's priorities "for my nation" (as distinct from responding to developing country priorities). The World Values Survey by Ronald Inglehart and his associates reveals (in surveys conducted around the world during 1995-2014) that most Western respondents rank "economic growth" below "more say on how things are done" and "beautiful cities and countryside" as goals for their country. The higher a country's GDP per capita, the fewer the number of respondents who put economic growth, income, jobs, or production among the top three priorities for their country - and vice versa.

Afrobarometer surveys ask African respondents, "In your opinion, what are the most important problems facing this country that the 
government should address?" The surveyors group respondents' top three priorities into eight categories. Problems concerning economic growth, jobs, incomes, and infrastructure fall within the top three priorities of between two thirds and three quarters of African respondents (in terms of country averages). By contrast, less than 10 percent of respondents put health and education in the top three priorities, and only 1 percent put "governance" or related terms in the top three. The contrast between these priorities and those of Western aid agencies is striking (Pritchett, 2015).

In short, as the Cold War wound down, Western aid agencies began to project into developing countries the priorities of their own Western publics "for themselves," such as health, education, and governance (as distinct from the priorities of developing country governments and publics). Also, Western governments, firms, and publics became alarmed at the growth of industry in developing countries (whose products were knocking out industries and employment at home) and opposed the use of "taxpayers' money" to boost the competition even more.

Western NGOs mobilized campaigns against infrastructure and industrial projects sponsored by the World Bank or aid agencies - projects such as the Bank's Polonoroeste road-paving and agricultural settlement project in the Brazilian Amazon in the 1980s, and the multi-dam-andirrigation Narmada project in western India. The Bank's response was to erect a series of environmental and social safeguard hurdles to be jumped by a wide range of infrastructure and industrial projects. Directly and indirectly, this led the Bank to scale back projects in these sectors and opt for "safe" projects in health, education, governance and the like instead. The latter were much more likely to advance the project officer's career, because preparation and Executive Board approval were much more likely to be plain sailing compared to a project in infrastructure or production.

In terms of development theory, the striking change of the 1980s and 1990s was the eclipse of the subdiscipline of development economics and the ascendancy of the idea of "mono-economics" - one unified body of (neoclassical) economic theory applicable to all countries, almost as universal as the laws of engineering. The argument for doing away with development economics was crystallized by Lal (1983) in The Poverty of 'Development Economics', published at about the same time as he became chief lieutenant of the World Bank's chief economist Anne Kreuger. They engineered a "cleaning of the stables" of the Bank's development economists, who were replaced by economists who believed, more reliably, in the virtues of the free market. At much the same time came a wave of 
literature arguing that the surging East Asian economies were succeeding because, above all, they had liberalized their markets and integrated more closely with the world economy (Wade, 1990). All this helped legitimize the change in zeitgeist about development, later crystallized by John Williamson in 1990 as "the Washington Consensus," meaning the consensus prevailing in Washington - and generally in the US and the West - about the single right recipe for developing countries. This consensus centered on letting and

making the market work, with governments focusing on that task as their central objective (along with reducing the incidence of extreme poverty).

\section{The World Bank}

All this may be accepted, but it leaves a puzzle. The most important influence on "development thinking" on a world scale is the World Bank, and a large majority of the Bank's members are developing countries. So why not more pushback from developing countries to the World Bank's agenda?

The short answer is that the Bank is governed largely by Western countries (or the West plus Japan). The much celebrated "voice reform" of 2010, which the Bank claimed to bring developing countries "almost to parity" (that is, almost to 50 percent of the votes) in fact left high-income countries (which do not borrow from the Bank) with 62 percent of the votes, leaving 38 percent for the middle- and low-income countries (Vestergaard \& Wade, 2012, 2015; Wade, 2013a, 2013b).

In response, developing countries are following a two-track strategy. The first, the "voice" strategy, is to keep pressing for a larger share of votes and senior positions, including an end to the American monopoly of the presidency and an end to the American veto (the US is the only country with a veto over super-majority decisions). The second is to facilitate "exit" - to create "bypass" organizations whose functions mimic those of the Bretton Woods organizations, but in whose governance developing countries have the predominant say. Cases in point are the Corporación Andina de Fomento, which in 2012 lent more for infrastructure in Latin America than the World Bank and the Inter-American Development Bank combined; the Asian Infrastructure Investment Bank, led by China, initiated in 2014; and the BRICS' Contingent Reserve Arrangement, also initiated in 2014.

\section{Conclusion}

I have argued that Western aid and development advice used to emphasize infrastructure and production. However, since the 1980s, partly 
propelled by the opportunity opened up with the ending of the Cold War, it has come to reflect a Western "humanitarian impulse" together with Western values about the good life (for Westerners); these do not sanction using "our" money to build "their prosperity" (but do approve of using our aid money to boost our own prosperity, as in the USAID mission statement quoted earlier). So governments, NGOs, and others at the receiving end of Western assistance should be appropriately cautious in accepting Western assurances that Western prescriptions for development really do reflect "mutual benefit" rather than partly "conflicting interests."

In the course of describing the nature of the change in Western developing thinking dating from the 1980s, I have examined the change in development vocabulary and grammar. Recall the passages quoted earlier from the 1969 and 2008 annual reports of the World Bank. Here is another example from the 2007 annual report:

IDA [international development assistance] has been moving toward supporting these strategies through program lending.

Notice that IDA has apparently not been doing, it "has been moving," and not even moving toward "doing" but only toward "supporting." Again, from 2008:

The Bank significantly accelerated its efforts to help client countries cope with climate change while respecting another aspect of its core mission: promoting economic development and poverty reduction by helping provide modern energy to growing economies [all emphases added].

The Bank has been accelerating, but accelerating only its efforts and only its efforts to help. Similarly, the headlines of the annual reports are full of gerunds or the present continuous verb tense: "providing timely analysis," "sharing knowledge," "improving governance," and "leveling the playing field on global issues" (Moretti \& Pestre, 2015).

This invocation of an infinitely expanding present where policies are always in progress, but only in progress, has several important effects. First, it supports the subliminal message of almost all World Bank reports: "progress has been made, but challenges remain." The Bank employs squadrons of editors to hardwire in this core message. 
Second, it renders the whole process of accountability obscure, for accountability must be assessed in relation to what has been done. Like many other organizations, the Bank is keen on its own accountability in theory, but less so in practice.

Third, the timeless and placeless language helps reinforce the tendency to think of development theory and policy as "free" of time and place, and free of the agents producing the policy paradigm and the specific policies - and, therefore, also free of contending ideas. The language itself contributes to acceptance of the idea that there is one unified economics, the laws of which are valid everywhere; at the level of policy, this implies that "there is no alternative."

A hegemonic bloc of states, like the West at present, has a built-in imperative to believe, and induce the periphery to believe, that policies and institutions that benefit the hegemon also benefit the periphery; that the world economy is an open system, not a constraining hierarchy; that the wise path of policies and institutions chosen by the hegemon are equally accessible to wise governments in the periphery; that the deep integration of all countries into the world economy - so that states have no more power to affect transactions, flows, and ownership transfers across their borders than do the states of the US - produces "mutual benefit." Hence, there is rightly no alternative.

This, in turn, helps explain the otherwise puzzling resilience of not just neoclassical but, more extreme, neoliberal and (German) ordoliberal beliefs after the North Atlantic Crash of 2008, in contrast to the rethinking that occurred after the two earlier twentieth-century crises in 1929 and the late 1970s. The beliefs are conceptualized in such timeless and placeless language as to be well protected from contradictory evidence or incompatible paradigms. At the same time, they sprinkle the equivalent of holy water on neoliberal political economy arrangements, which sluice a substantial proportion of national income into the hands of the top 1 percent: 23 percent in the past few years in the US, 29 percent in Brazil, about one third in that paragon of the Washington Consensus, Chile. Elites in developing countries, including members committed to national development (including to industrialization) may well be uneasy about challenging neoliberal beliefs and their Washington Consensus expression, which deliver to them such a commanding position in their own societies.

What to do? Wisdom starts by recognizing just how difficult, how uncommon, is sustained economic growth. In the past two centuries, the 
number of non-Western countries that have become "developed" is fewer than ten, most of which have small populations. The second point is that just about all of them (Hong Kong is a partial exception) had governments that implemented a vigorous industrial policy, complete with mediated integration between nurtured sectors and the international market so that they were subject to international competitive pressure, but in a buffered way (Wade, 1990).

The third point is that, today, industrialization - and the growth of a diversified production structure - will almost certainly have to be at the center of a development process capable of achieving developed country status. Kaldor's "growth laws" - that the rate of growth of productivity in manufacturing and in nonmanufacturing are a function of the rate of growth of manufacturing output - are, broadly, empirically confirmed. The fourth point is that "government intervention" to impart directional thrust to industrialization can certainly protect gross inefficiencies and undynamic sectors (think of the highly protected Indian car industry until the liberalization of the early 1990s), but if the promotion instruments are linked to performance against international benchmarks, industrial policy can be effective in building competitive industrial competences - even in the face of Chinese competition. 


\section{References}

Lal, D. (1983). The poverty of 'development economics' (Hobart Paperback No. 16). London: Institute of Economic Affairs.

Lin, J. Y. (2012). From flying geese to leading dragons: New opportunities and strategies for structural transformation in developing countries. Global Policy, 3(4), 397-409.

Moretti, F., \& Pestre, D. (2015). Bankspeak: The language of World Bank reports. New Left Review, 92, 75-99.

Orwell, G. (1968/1946). The collected essays, journalism and letters of George Orwell: In front of your nose 1945-50 (S. Orwell \& I. Angus, eds.) (vol. IV). Harmondsworth: Penguin.

Pritchett, L. (2015). Can rich countries be reliable partners for national development? Horizons, 2, 206-223.

Vestergaard, J., \& Wade, R. (2012). Establishing a new Global Economic Council: Governance reform at the G20, the IMF and the World Bank. Global Policy, 3(3), 257-269.

Vestergaard, J., \& Wade, R. (2015). Still in the woods: Gridlock in the IMF and the World Bank puts multilateralism at risk. Global Policy, 6(1), $1-12$.

Wade, R. (1990). Governing the market: Economic theory and the role of government in East Asian industrialization. Princeton, NJ: Princeton University Press.

Wade, R. (2013a). The art of power maintenance: How western states keep the lead in global organizations. Challenge, 56(1), 5-39.

Wade, R. (2013b). Protecting power: Western states in global organizations. In D. Held \& C. Roger (Eds.), Global governance at risk (pp. 77-110). Cambridge: Polity Press. 